\title{
PANDEMIA E DIREITOS HUMANOS: REFLEXÕES SOBRE (AB)USOS DA METÁFORA DA GUERRA
}

\author{
PANDEMIC AND HUMAN RIGHTS: REFLECTIONS ON THE WAR METAPHOR AND ITS (AB)USES \\ PANDEMIA Y DERECHOS HUMANOS: REFLEXIONES SOBRE (AB)USOS DE LA METÁFORA \\ DE LA GUERRA
}

\author{
Jacqueline de Oliveira Moreira* \\ Carlos Roberto Drawin ${ }^{* *}$ \\ Domingos Barroso da Costa ${ }^{* * *}$ \\ Ana Carolina Dias Silva***
}

\begin{abstract}
RESUMO
Questionamo-nos se a vinculação da covid-19 ao significante "guerra" poderia esvaziar a força legal da Declaração dos Direitos Humanos, atingindo-a em seu pilar fundamental: a dignidade humana. Retomamos as consideraçóes de Clausewitz, para quem, não se constituindo como episódio inesperado, a guerra consiste em continuação da política, para chegar a Foucault, que desvela que as relações de poder produzem uma regulamentação da vida e da morte, o que nos relança no campo de vulnerabilidade que a metáfora bélica indica e oculta. No momento dramático da pandemia, a convocação de todos para a guerra, a convocação solidária contra o inimigo comum, embora justificável como medida de emergência e apelo necessário para o isolamento social, também pode servir como anverso da necropolítica (Mbembe, 2016), a morte visível produzida pelo vírus revestindo a morte invisível dos excluídos e descartáveis, dos “matáveis” de sempre.
\end{abstract}

Palavras-chave: Pandemia. Direitos humanos. Metáfora da guerra. Necropolítica.

\footnotetext{
Texto recebido em 10 de abril de 2020 e aprovado para publicação em 30 de maio de 2020. Agência de fomento: Coordenação de Aperfeiçoamento Pessoal de Nível Superior (Capes).

"Doutora em Psicologia Clínica pela Pontifícia Universidade Católica de São Paulo (PUC-SP), mestra em Filosofia pela Universidade Federal de Minas Gerais (UFMG) e graduada em Psicologia pela UFMG, docente de Psicologia no Programa de Pós-Graduação da Pontifícia Universidade Católica de Minas Gerais (PUC Minas), bolsista de produtividade PQ2 - CNPq. Perfil no site Orcid: https://orcid.org/0000-0003-0901-4217

"* Doutor e mestre em Filosofia, graduado em Psicologia e bacharel em Filosofia pela UFMG, professor aposentado do Departamento de Filosofia da UFMG e professor titular na Faculdade Jesuíta de Filosofia e Teologia (Faje). Perfil no site Orcid: http://orcid.org/0000-0002-3497-671X

${ }_{* * *}^{*}$ Doutorando no Programa de Pós-Graduação em Psicologia da PUC Minas, mestre em Psicologia e especialista em Criminologia pela PUC Minas, especialista em Direito Público pela Unigranrio, graduado em Direito pela UFMG, defensor público no Rio Grande do Sul, com atuação nos Tribunais Superiores. Perfil no site Orcid: https://orcid.org/0000-0001-5796-7480

**** Doutoranda no Programa de Pós-Graduação em Psicologia da PUC Minas, área de concentração Processos de Subjetivação, linha de pesquisa Processos Psicossociais, mestra em Psicologia pela PUC Minas, bolsista Capes Prosuc Modalidade I, psicóloga pela UFMG, com ênfase em Processos Clínicos e formação complementar aberta em Subjetividades Políticas e Territórios. Perfil no site Orcid: https://orcid.org/0000-0002-5448-7622
} 


\begin{abstract}
We wonder if linking the Covid-19 pandemic to the signifier "war" could wither away the legal force of the Universal Declaration of Human Rights, hitting it to its core: human dignity. We pick up on Clausewitz's considerations, for whom war consists of the continuation of politics rather than of an unexpected episode, to get to Foucault, who unveils that power relations produce a regulation of life and death, what cast us again in the field of vulnerability, one that the war metaphor either arouses and conceals. At the dramatic moment of the pandemic, the call for war, the supportive call against a common enemy, although justified as an emergency measure and necessary appeal, may also be of avail as the necropolitics obverse (Mbembe, 2016), the visible death produced by the virus enshrouding the invisible death of the excluded and disposable, the usual "killable" ones.
\end{abstract}

Keywords: Pandemic. Human rights. War metaphor. Necropolitics.

\title{
RESUMEN
}

Nos preguntamos si el vínculo entre Covid-19 y el significante "guerra” podría vaciar la fuerza legal de la Declaración de Derechos Humanos, golpeando su pilar fundamental: la dignidad humana. Volvemos a las consideraciones de Clausewitz, para quien la guerra consiste en una continuación de la política y no es un episodio inesperado, para llegar a Foucault, quien revela que las relaciones de poder producen una regulación de la vida y la muerte, que vuelve a echarnos en el campo de la vulnerabilidad que la metáfora bélica indica y oculta. En el dramático momento de la pandemia, el llamado de todos a la guerra, el llamado de solidaridad contra el enemigo común, aunque justificable como una medida de emergencia y un llamado necesario al aislamiento social, también puede servir como el anverso de la necropolítica (Mbembe, 2016), la muerte visible producida por el virus que cubre la muerte invisible de los excluidos y desechables, de los "asesinables" de siempre.

Palabras clave: Pandemia. Derechos humanos. Metáfora de guerra. Necropolítica.

\section{A COVID-19 E A METÁFORA DA GUERRA: CONFIGURAÇÕES MIDIÁTICAS}

Cabemos que o horror de duas guerras mundiais impulsionou a produção da Declaração Universal dos Direitos Humanos, em 1948, pela qual a dignidade humana foi alçada à posição de referencial metajurídico dos ordenamentos ocidentais, com o que se visava a evitar novos episódios de reificação do sujeito, tais como os observados destacadamente nas ações nazistas. Em síntese, com 
a Declaração, a máxima kantiana segundo a qual a vida humana, não tendo equivalente ou preço, é caracterizada por sua dignidade intrínseca (Kant, 2019), foi gravada como limite ético dos ordenamentos jurídicos de seus signatários, de modo que toda a elaboração, a interpretação ou a aplicação de seu direito deveriam ser atravessadas por esse ideal, evitando-se, assim, que genocídios fossem autorizados e induzidos pelo próprio direito.

Podemos, inclusive, pensar que existe uma contraposição entre o termo guerra e o respeito à dignidade humana, bem como a direitos fundamentais que conferem substância a essa ideia. E é exatamente na distância entre a noção de guerra e dos direitos fundamentais à vida, à liberdade, à igualdade, entre outros, que se situa nosso incômodo com relação à metáfora da guerra para pensar a pandemia do novo coronavírus. Questionamo-nos se (e em que medida) a vinculação da covid-19 ao significante "guerra" poderia esvaziar a força legal da Declaração dos Direitos Humanos, atingindo-a, implícita ou explicitamente, justo em seu pilar fundamental: a dignidade humana. A esse respeito, cabe relembrar a advertência freudiana diante da indagação Por que a guerra?, formulada em sua carta a Einstein: "As leis são feitas por e para os membros governantes e deixa pouco espaço para os direitos daqueles que se encontram em estado de sujeição" (Freud, 1932-1933/1969, p. 200). ${ }^{1}$

Questionamo-nos também quanto ao que se procura comunicar e ao que se procura velar no momento em que se (ab)usa da metáfora da guerra para tratar das açóes empreendidas no enfrentamento da crise sanitária determinada pela pandemia do novo coronavírus.

No sentido, portanto, de organizar nossas indagações e considerações, voltamos ao dia 26 de março de 2020, quando, durante a Cúpula Extraordinária de Líderes do G20, o diretor-geral da Organização Mundial de Saúde afirmou estarmos "em guerra com um vírus que ameaça nos desmantelar - se deixarmos" (World Health Organization, 2020, tradução nossa). Todavia, a preposição essencial "com" articula o vírus à guerra. Assim, trata-se de uma batalha contra o vírus. De outro lado, encontramos um deslizamento do significante "guerra" que pode ressaltar a força da metáfora de pensar que estamos em guerra, retirando, pois, a preposição essencial. Afirmar "estamos em guerra com o vírus" não significa o mesmo que "estamos em guerra". Aliás, há mesmo de se questionar se é possível estar em guerra com um vírus, o que também mobiliza as indagações e considerações articuladas ao longo deste estudo. Nesse contexto, apesar de imputar um cenário beligerante como predicativo a combate ao vírus, Tedros Adhanom Ghebreyesus adiciona à solicitação de luta duas outras forças alheias

1 A primeira data indica o ano de publicação da obra, e a segunda, a edição consultada pelo autor, a qual somente será pontuada na primeira citação da obra no texto. Nas seguintes, será registrada apenas a data de publicação original. 
à arte da guerra: a solidariedade global e o poder industrial das naçôes para o combate solidário ao novo coronavírus (World Health Organization, 2020).

Interessa-nos, pois, primeiramente, refletir sobre os perigos de fixar o tema da pandemia como uma guerra em si e não como uma guerra "com" o vírus. Nesse sentido, em 16 de abril de 2020, o portal BBC News Brasil publicou reportagem intitulada "É como ir para a guerra sem nenhuma arma": médicos e MP relatam caos no Amazonas com a pandemia (Senra, 2020). Um mês antes, o governo do Amazonas já havia decretado emergência em saúde pública no Estado. $\mathrm{Na}$ penúltima semana do mês de abril, um vídeo chocou o País ao mostrar a abertura de valas comuns pela Prefeitura de Manaus para enterrar vítimas do novo coronavírus, após anúncio da instauração de contêineres frigoríficos em cemitério. Segundo reportagem do G1, "Em uma coletiva de imprensa realizada na quinta-feira (16), o Governo do Amazonas admitiu que o sistema de saúde do estado já apresentava insuficiência da capacidade de leitos do Sistema Único de Saúde (SUS) antes da pandemia da covid-19" (Nascimento, 2020).

A reportagem veiculada pela $B B C$ News abordou profissionais de saúde denunciando a precariedade da situação de trabalho: hospitais superlotados, escassez de equipamentos de proteção individual, falta de testes e exames, além de atrasos nos pagamentos. Para médicos ouvidos pela reportagem, a crise expôs um problema antigo no Estado. "“[. . .] sempre usam a saúde como massa de manobra para poderem se eleger, mas de efetivo não faziam nada. Isso tem anos já' [. . . 'Agora, a pandemia do coronavírus mostrou o tamanho da deficiência da saúde aqui no Amazonas"” (Senra, 2020).

Em 29 de março, o portal já havia publicado matéria a respeito de estratégias de prevenção à disseminação do vírus: "Brasil deveria fazer 'esforço de guerra' para manter as pessoas em casa, diz economista da Universidade de Chicago", Luigi Zingales (Sanches, 2020). Em defesa do isolamento social como principal medida de atenuação da situação pandêmica, a discussão girou em torno do cenário econômico que se impôs a partir da proposta de confinamento. A noção de "combate à pandemia" apareceu diretamente ligada à discussão políticoeconômica, revelando a importância de uma reflexão quanto à dignidade humana a partir da situação de crise sanitária decorrente da pandemia e de sua designação como uma "guerra contra o novo coronavírus".

Quanto à pergunta sobre o impacto econômico do vírus, o economista respondeu: "Em uma situação de guerra, você resolve primeiro o perigo mais iminente, depois se preocupa com o resto. E o principal problema agora é conter o espalhamento da doença". Questionado sobre estratégias, acrescentou: "Vejo uma provável necessidade de criar impostos sobre grandes fortunas, porque, 
durante guerras, seus meios de financiar um país são basicamente imprimindo dinheiro ou criando alguma maneira de taxar riquezas" (Sanches, 2020).

No que tange às inquietaçôes acerca do que desvela e o que vela o uso da metáfora da guerra diante da pandemia, observamos que o jornal português Público, utilizando-se dessa metáfora, veiculou, em 29 de abril, uma denúncia: "Covid-19: Presidente de El Salvador usa pandemia para fazer guerra aos gangs" (Fernandes, 2020). Já há muito, os chamados "gangs" eram apresentados pelas autoridades salvadorenhas como grave questão de segurança social naquele país. Herdeiros de um contingente populacional que emigrou para os Estados Unidos a fim de escapar da guerra civil que arruinou o país centro-americano por 12 anos (até 1992), os "gangs", em El Salvador, constituíram-se majoritariamente de jovens deportados com cadastro criminal. "Com o vazio governativo e a pobreza dos seus países de origem, os membros dos gangues reproduziram as suas estruturas sociais e as suas tácticas, multiplicando-se exponencialmente" (Motlagh, 2019).

O boom de tais estruturas, conjugado ao cenário econômico precário, intensificou conflitos e, consequentemente, a violência urbana. Com estratégias de micro e macroextorsão, tráfico de drogas e armas, os "gangs" controlam grandes áreas urbanas em El Salvador. A situação pandêmica colocada pela chegada do novo coronavírus mobilizou parte da organização. De acordo com o jornal $E l$ faro, que entrevistou integrantes das gangues (inclusive rivais), além de outros atores civis, as facções haviam aderido ao isolamento social em consonância com medidas governamentais, impondo, inclusive, restrições de circulação por meio de ameaças aos moradores das áreas por elas controladas. Algumas haviam até mesmo suspendido as taxas de extorsão à população durante o período de interrupção das atividades comerciais. As razões se diversificam entre os "gangs", passando pelo receio de ausência de atendimento médico aos integrantes ou prevenção da presença da polícia nos bairros. A reportagem apontou diminuição de homicídios, furtos e também roubos.

Um aumento abrupto de mortes, porém, no fim do mês de abril de 2020, sem motivaçôes confirmadas, desencadeou retaliação governamental: o presidente ordenou uma ação emergencial nos centros prisionais. Placas de metal seriam colocadas nas portas das superlotadas celas, que passariam por uma inspeção geral. Enfileirados, seminus, os presos aguardavam nos pátios das prisões as operaçôes policiais sem condiçôes mínimas de higiene, aumentando o risco de contágio. As ordens presidenciais incluíam a reorganização dos presos de maneira a submeter integrantes de gangues rivais ao mesmo espaço de clausura, o que se evitava havia mais de uma década. A reportagem pontuou: "As medidas já ameaçam transformar, por si sós, as prisões num palco de guerra e que esta 
extravase os seus muros - os gangs tendem a retaliar nas ruas -, mas, em contexto de pandemia, o risco é ainda maior" (Fernandes, 2020).

Vemos como um discurso das autoridades sanitárias a respeito do combate ao vírus, passando pelas implicaçóes e desafios econômicos decorrentes do isolamento social, acaba por chegar à questão da criminalidade, desenhando um cenário de extrema violência e completa violação a direitos fundamentais, enfim, de esvaziamento da noção de dignidade humana, que haveria de ser o norte para toda criação, interpretação ou aplicação do direito após a Declaração Universal dos Direitos Humanos, de 1948. Esse deslizamento dos temas e problemas não é fortuito e, de certa forma, já está embutido na "metáfora da guerra". Quem guerreia contra quem? A humanidade, como uma totalidade solidária, contra o vírus considerado como um estranho e misterioso inimigo invisível? No que se segue, propomos uma pequena reflexão sobre a inter-relação entre a pandemia tratada sob a ótica da guerra e os direitos humanos.

\section{GUERRA E DIREITOS HUMANOS}

Já decorreram quase 250 anos desde a primeira declaração formal, consagrando os direitos humanos como exigência basilar da vida social. Todavia parece evidente o quão distantes estamos (comunidades particulares, grandes nações e povos, bem como o próprio conjunto da humanidade) de sua efetiva realização. No momento dramático da pandemia de covid-19, o futuro de nossa civilização se oculta na espessa nebulosidade de inúmeras incertezas. Alguns creem que a época pós-pandemia poderá testemunhar maior solidariedade entre as pessoas e maior cuidado com a qualidade de vida e com o meio ambiente. Outros temem, e já discernem no presente, grandes ameaças às liberdades, a direitos individuais e ao bem comum. A experiência histórica recente, com sua procissão de genocídios, ditaduras, massacres e guerras, parece nos apontar o caminho da prudência ou para aquela atitude que o filósofo alemão Jonas (2006) designou como "heurística do medo", ou seja, seria preferível temer os riscos já contidos no presente, no empenho de evitar que ocorram no futuro, do que desconsiderálos e ser por eles surpreendidos.

Agravíssimacrise econômica na qual já estamos mergulhados não seráfacilmente superada e, por conseguinte, após as emergências sanitárias da pandemia, tudo parece indicar que os conflitos de interesse estarão mais acirrados. Quais consequências poderiam advir daí? Entre muitos efeitos possíveis, certamente o processo de precarização da previdência (da seguridade social, como um todo) e do trabalho, já em curso, será intensificado num contexto de grave desemprego, em que as possibilidades de negociação entre patrões e empregados serão muito 
restritas, escancarada a preponderância do poder econômico em prejuízo dos que dependem exclusivamente de sua força de trabalho para sobreviver. Aliás, a necessidade e a sobrevivência tendem a ser os principais reguladores das relações entre patróes e empregados num cenário de ruína econômica, a perspectiva da fome falando mais alto que qualquer noção de direitos ou consciência de classe.

As insatisfações e demandas, no entanto, não são eliminadas magicamente pelo fato de não poderem ser atendidas. Contidas e frustradas, elas ainda mais se exacerbam, podendo provocar revoltas ocasionais, explosões erráticas de violência ou manifestações infrapolíticas, como vemos na criminalidade endêmica a se espraiar em nossos grandes centros urbanos. O que poderá, então, ocorrer?

A emergência da pandemia mostrou a importância da intervenção estatal e, em alguns países, como a China, mostrou a eficácia racional e os ganhos sanitários obtidos pela vigilância intensiva e extensiva das populações, colocando em xeque as bases das propostas neoliberais. Sabemos que, em nome da guerra ao crime e à anarquia social, não é incomum justificar a implantação de extensos mecanismos de controle, com respaldo jurídico mais ou menos consistente, de modo a garantir o que poderia ser paradoxalmente denominado como um "estado normalizado de exceção". A noção foi desenvolvida por Agamben (2004), ao mostrar que, nas democracias contemporâneas, o "estado de exceção" é um paradigma de governo. Ou seja, em nome da ordem democrática supostamente contestada pela guerra, pela anarquia, pelo crime e por diversas formas de ameaça à segurança, são criados mecanismos jurídicos de controle da liberdade e dos direitos individuais e de intervenção na esfera privada. Ora, como as ameaças à ordem democrática jamais cessam o "estado de exceção", em princípio provisório, passa a ser normalizado, apresentando-se "muito mais como uma técnica de governo do que como uma medida excepcional, mas também deixa aparecer sua natureza de paradigma constitutivo da ordem jurídica" (Agamben, 2004, p. 18). Ora, a "guerra contra o novo coronavírus" atribui metaforicamente a uma entidade não humana uma intencionalidade humana, a de um inimigo perigoso, que nos ameaça e ataca a vida e a liberdade, contra o qual, portanto, declaramos guerra, investindo nossas forças no sentido de neutralizá-lo e destruí-lo.

Aqui cabe uma breve observação sobre o papel da metáfora. Não existe experiência humana que seja um contato direto e imediato com algo que poderia ser chamado de "realidade". Toda experiência humana, mesmo a experiência de seu ambiente natural mais próximo e de seu próprio corpo, é simbolicamente mediada ou, como enfatiza Geertz, é apreendida por meio de uma rede de interpretações, não há descrição de um fato que já não esteja envolvido em interpretações, o comportamento humano seria caótico se não orientasse por "sistemas organizados de símbolos significantes" (Geertz, 1978, p. 58) 
Por isso a linguagem humana não é meramente descritiva e presa ao imediato das situaçōes, o uso metafórico que lhe é inerente, servindo para produzir algum tipo de impacto afetivo na comunicação, mas também para estabelecer associativamente uma constelação de significados. Pela metáfora, portanto, os significados deslizam, associam-se e até se substituem, produzindo efeitos que transcendem a mera descrição, tocando, mesmo, as sensações de quem se comunica, de modo que a mensagem acaba apreendida em maior extensão (ainda que jamais completamente, já que sempre deixa restos em sua transmissão).

Ora, a guerra é um fenômeno humano universal e traumático, presente nas mais diversas latitudes e épocas, e está associado a experiências de dor, violência, perda e a alguma ameaça proveniente do exterior. Nas guerras, há certo estranhamento com relação ao outro: o outro povo, nação ou cultura. A palavra "guerra", associada a uma constelação de significações, é usada com frequência quando queremos identificar um inimigo, uma ameaça vinda do exterior e que pode nos afetar gravemente. É o que se vê em expressóes como "guerra às drogas", "ao crime", "ao terrorismo" e outras, que bem podem ilustrar alguns destes significados: ameaça, exterioridade, dano, afetação; bem como justificar os meios, mesmo excepcionais, para deles nos defendermos.

Clausewitz, militar e teórico prussiano (1780-1831), em frase largamente conhecida, definiu a guerra como a política sendo feita por outros meios (Clausewitz, 2010). Quando os esforços de negociação política se esgotam, os conflitos entre as nações, antes mediados diplomaticamente, eclodem com violência. Quando faltam palavras, resta o ato: cessa o jogo regrado da política e, em seu lugar, dá-se o confronto cruento e incontrolável. Ora, o "estado normalizado de exceção" (Agamben, 2004) é justamente a guerra sendo feita por outros meios, talvez menos ruidosos, mais velados, mas não menos violentos: o cerceamento dos direitos, a vigilância generalizada, a usurpação das conquistas sociais. A ironia da situação é que a violação dos direitos poderá ser feita em nome dos interesses declarados de uma determinada sociedade quando a sua real motivação é justamente o inverso: os interesses particulares se impondo sob o rótulo do benefício universal. Trata-se de um jogo de luz e sombras em que o discurso oficial se dá em ocultação aos reais intuitos de quem detém o poder, tendo como finalidade a manutenção do status quo.

Apesar de os direitos humanos terem obtido credibilidade universal e terem sido incorporados ao patrimônio moral da humanidade, a ponto de serem continuamente invocados, mesmo por governos que os violam despudoradamente (o que chama a atenção para sua elevada força simbólica e, ao mesmo tempo, para sua pouca concretude), sua efetivação é lenta, frágil e sujeita a inúmeros retrocessos, justamente porque se apresentam como limites racionais a um 
poder que sempre tende a desbordar no sentido da fixação das relaçôes de força entre dominantes e dominados. A Declaração Universal dos Direitos Humanos, proclamada em 1948 pela Organização das Nações Unidas, desde seu primeiro artigo, não deixa dúvidas em relação ao princípio do respeito à dignidade humana, pois cada ser humano, em sua singularidade, guarda um valor único e intrínseco: "Todos os seres humanos" - reza o primeiro artigo - "nascem livres e iguais em dignidade e em direitos. Dotados de razão e de consciência, devem agir uns para com os outros em espírito de fraternidade".

Ora, a declaração das Nações Unidas tornou-se possível somente após a imensa catástrofe da Segunda Guerra Mundial e seus efeitos traumáticos; diante do transbordamento da força e do impulso de dominação. Surgiu, portanto, como uma referência fundamental (e racional) para exorcizar a ameaça de novas tiranias como aquelas que desencadearam a guerra. Do mesmo modo, as primeiras declarações dos direitos humanos do final do século XVIII (a "Declaração de Independência dos Estados Unidos", de 1776, e a "Declaração dos Direitos do Homem e do Cidadão", de 1789) emergiram após lutas encarniçadas contra a tirania. Ou seja, os direitos humanos não surgem da consciência jurídica como uma espécie de deus ex machina, mas resultam de longos anos de duros combates sociais e não poucas derrotas que aos poucos vão se sedimentando em processos psicossociais até o momento de sua explícita manifestação institucional. As guerras prévias às proclamações dos direitos humanos (a Guerra de Independência nos Estados Unidos, a Revolução Francesa e a guerra contra o nazifascismo) podem ser consideradas como um último recurso quando todas as alternativas políticas foram inviabilizadas.

Para Clausewitz (2010), a teoria da guerra é permeada pelos extremos de força, mas o propósito político que subjaz a uma guerra comporta uma diversidade de aspectos, entre os quais o autor enfatiza três:

$\mathrm{O}$ primeiro destes três aspectos diz respeito principalmente às pessoas; o segundo ao comandante e ao seu exército; o terceiro ao governo. As paixões que serão inflamadas na guerra já devem ser inerentes às pessoas. A liberdade de ação que o jogo de coragem $\mathrm{e}$ talento desfrutará na esfera da probabilidade e do acaso dependerá do caráter específico do comandante e do exército, mas os propósitos políticos são apenas um assunto do governo (p. 93).

Ao indicar a potencial ameaça de desmantelamento do mundo pelo novo coronavírus, o diretor-geral da OMS aponta um extremo de força destruidora em um campo de acaso e probabilidades que certamente têm efeitos no pathos. Mas de que se trata quando pensamos o propósito político no que se refere a um agente viral? Ainda em Clausewitz (2010) encontramos que 
A guerra nada mais é do que um duelo em grande escala. Inúmeros duelos fazem uma guerra, mas pode ser formada uma imagem dela como um todo, imaginando-se um par de lutadores. Cada um deles tenta, através da força física, obrigar o outro a fazer a sua vontade. O seu propósito imediato é derrubar o seu oponente de modo a torná-lo incapaz de oferecer qualquer outra resistência. A guerra é, portanto, um ato de força para obrigar o nosso inimigo a fazer a nossa vontade. (p. 75, grifo do autor).

De fato, podemos pensar que há um engajamento contra uma crise sanitária mundial em jogo, mas não podemos conceber um par de lutadores nesse combate, determinados por consciência e intençôes. O vírus não objetiva subjugar-nos para que façamos sua vontade. Ao vírus só resta ser vírus. Ele é um agente natural, cujos elevados poderes de contágio e capacidade patogênica impõem "Emergência de Saúde Pública de Importância Internacional" ("OMS declara coronavírus...", 2020). Entretanto não deixamos de refletir a respeito do surgimento de uma mobilização econômica, política, social e cultural que deveria ser direcionada à erradicação dessa ameaça virulenta, mas que termina revestida de uma narrativa bélica ao considerarmos, em tal equação, as dinâmicas de poder e dominação nas dimensões local, regional e global. O que, portanto, o termo "guerra", que encontramos facilmente em indicações diretas ou alusões à pandemia, tem de ambiguidades?

Para Clausewitz (2010), três extremos organizam a noção teórica da guerra: não existe limite lógico para uso da força; o poder de resistência e o emprego máximo da força elevam ao ápice de sua potência os esforços oponentes; a indefensabilidade do oponente é a estratégia visada da guerra. Em teoria, portanto, um cenário de guerra implica o objetivo de submissão do oponente a um contexto de vulnerabilidade extrema. Considerando que toda guerra é sobredeterminada por fatores ocorridos no mundo político e, por isso, "nunca irrompe de uma maneira totalmente inesperada, nem pode alastrar-se instantaneamente" (Clausewitz, 2010, p. 79), como pode a eclosão de um vírus com alta taxa de transmissibilidade, causador de síndrome respiratória aguda grave, compor todo um cenário bélico?

Para Clausewitz (2010), a arte da guerra não se ocupa de evitar os extremos no "derramamento de sangue": "inserir o princípio da atenuação na própria teoria da guerra levaria sempre a um absurdo lógico" (p. 76); pelo motivo mesmo de que a guerra não está totalmente submetida à lógica e, assim, não se detém ante o princípio da não contradição. Escapa, então, às dinâmicas da guerra a preocupação em estabelecer sérias e restritivas diretrizes de prevenção à disseminação do vírus em diversos âmbitos de vigilância epidemiológica, visando à atenuação de significativas perdas humanas; o que, por si, já indicaria a impertinência da metáfora bélica associada ao vírus. Mas vemos surgir no discurso político uma 
força contrária, dissimulada em indicadores econômicos, que, belicamente, não se ocupa de atenuar as consequências à vida humana, velando e desvelando em uma ambiguidade sórdida as relaçôes de poder.

Afinal, como pontua Clausewitz (2010),

Quando comunidades inteiras vão à guerra - naçôes inteiras e, principalmente, nações civilizadas - o motivo é sempre alguma situação política, e o acontecimento sempre devese a algum propósito político. A guerra é, portanto, um ato de política. Fosse ela uma manifestação de violência total, livre de restriçōes e absoluta (como exigiria o seu conceito puro), usurparia por sua própria e independente vontade o lugar da política no momento em que esta fosse posta em vigor (p. 90).

Não se constituindo como episódio autônomo ou inesperado, a guerra consiste em "um verdadeiro instrumento político, uma continuação das relações políticas realizada com outros meios" (Clausewitz, 2010, p. 91).

Discutindo sobre dispositivos de poder, e lançando uma pergunta a respeito da imbricação entre relações de poder e relações econômicas, Foucault (2005) após indicar que "o poder é essencialmente o que reprime" (p. 21), propõe a seguinte interrogação:

Se o poder é mesmo, em si, emprego e manifestação de uma relação de força, em vez de analisá-lo em termos de cessão, contrato, alienação [noção que aparece na teoria jurídica clássica] em vez mesmo de analisá-lo em termos funcionais de recondução das relaçóes de produção [concepção marxista mais geral sobre o poder], não se deve analisá-lo antes e acima de tudo em termos de combate, de enfrentamento ou de guerra? (p. 22).

Se adicionamos as relações de poder como importante elemento na configuração da "guerra" à covid-19, o desvelamento foucaultiano da inversão da proposição em Clausewitz nos é de grande valia: "a política é a guerra continuada por outros meios" (Foucault, 2005, p. 23). Assim, o propósito político da guerra se revela invertido no que seria fundamentalmente o propósito bélico da política: "O poder político, nessa hipótese, teria como função reinserir perpetuamente essa relação de força, mediante uma espécie de guerra silenciosa, e de inseri-la nas instituiçôes, nas desigualdades econômicas, na linguagem, até nos corpos de uns e de outros" (Foucault, 2005, p. 23).

Nesse regime, as relações de poder passam a produzir discursos de verdade que, por serem a norma, ao mesmo tempo, produzem efeitos de poder e uma regulamentação da vida e da morte, o que nos relança no campo de vulnerabilidade que a metáfora bélica indica e oculta. 
Pobreza, desemprego, aumento da miséria social, escassez de políticas públicas de saúde, educação, planejamento urbano, segurança, entre outras, retrocesso nas garantias de direitos civis e sociais são problemas antigos (e estrategicamente conservados) de países em que historicamente a desigualdade social impera. A hesitação ante a dignidade humana, que mostra sua face na construção narrativa de um falso dilema entre salvar vidas ou salvar a economia (como se a vida humana não fosse pressuposto da economia), desnuda que o poder tem como instrumento a guerra. Logo, a suposta guerra que explode no cenário epidemiológico mundial configura-se como manifestação de um desequilíbrio de forças que primordialmente constitui o tecido social, a metáfora veiculando em sua superfície a ideia de união contra um inimigo comum, ao mesmo tempo em que encobre manifestaçõos extremas de poder em relações intestinas de opressão já cristalizadas, no interior das quais as vidas não têm igual dignidade, mas pesos e preços diferentes.

Emerge, assim, o problema da dominação e da sujeição no centro da discussão a respeito do direito, na apreensão do poder em suas extremidades cada vez menos jurídicas e em seus processos contínuos e ininterruptos, que configuram o poder que funciona em cadeia.

Para Foucault (2005), "Com o desenvolvimento dos Estados [. . .], as práticas e as instituições de guerra" evoluíram rapidamente, ocorrendo uma centralização do poder. "Com isso, pelo fato dessa estatização, encontrou-se apagado do corpo social, da relação de homem com homem, de grupo com grupo, aquilo que se poderia chamar de guerra cotidiana, aquela que chamavam efetivamente 'guerra privada” (p. 55). Nesse cenário em que a guerra é, “ao mesmo tempo, centralizada em sua prática e recuada para a sua fronteira [do Estado]" (p. 56), surge um discurso em que não há um sujeito universal, mas adversários:

Nessa luta geral de que ele fala, aquele que fala, aquele que diz a verdade, aquele que narra a história, aquele que recobra a memória e conjura os esquecimentos, pois bem, este está forçosamente de um lado ou do outro: ele está na batalha, ele tem adversários, ele trabalha para uma vitória particular (Foucault, 2005, p. 60).

É nesse âmbito que Foucault pode afirmar que o discurso é sempre um discurso de perspectiva. Assim entendemos a produção da verdade que se revela na sustentação de um protecionismo político e econômico em detrimento ao próprio princípio de dignidade humana, negligenciando a primordialidade de oferta de políticas sociais em consonância com as recomendações de saúde pública das autoridades nacionais e internacionais. ${ }^{2}$

\footnotetext{
2 Em 31 de março de 2020, a Organização Pan-Americana de Saúde havia publicado uma convocação à ação urgente nas Américas para desaceleração da propagação do vírus, incluindo medidas preventivas enérgicas, como o distanciamento social (Etienne, 2020).
} 
Se, com Clausewitz, localizamos que o predicativo belicoso na referência à corrida pela erradicação do novo coronavírus é inapropriado em diversos pontos, com Foucault refletimos que as relações de poder envolvidas nesse processo desvelam um caráter histórico-político de combate. A partir desse ponto de vista, temos o novo coronavírus tomado como eixo de sustentação retórico para um discurso bélico que, aparentemente, é capaz de unir em torno de um inimigo comum (o vírus), mas que, de fato, termina por encobrir as verdadeiras guerras que se travam no interior de um determinado agrupamento, a letalidade do inimigo atuando mais livremente ante uns (os dominados) que outros (os dominantes), o vírus apresentando-se, assim, como um elemento oportuno e auxiliar na fixação das relações de poder em jogo. Tem-se "um entrecruzamento de corpos, de paixóes e de acasos: é isso que, nesse discurso, vai constituir a trama permanente da história e das sociedades" e que está vinculada “à astúcia e à maldade daqueles que, tendo por ora a vitória, e estando favorecidos na relação de dominação, têm todo interesse de não as pôr de novo em jogo" (Foucault, 2005 , p. 64), ao próprio custo da vida humana.

Rodríguez (2020) sugere que

Nesta crise a metáfora bélica está muito presente. Sua utilização resulta problemática porque se bem evoca imagens como resistência ou heroísmo, de conotações positivas, também remete a outras, como enfrentamento, obediência ou inimigo, que denotam conflito. Por outra parte, tampouco está claro porque ante uma situação de emergência sanitária não se recorre a outros marcos mais relacionados com o cuidado, a empatia ou a solidariedade (p. 32, tradução nossa).

A discussão foucaultiana ressalta a ambivalência da metáfora bélica que, por um lado, desmascara o conflito inerente às nossas sociedades, marcadas pela desigualdade e a injustiça, por outro, pode justificar como inevitáveis o arbítrio e a opressão, escamoteando a gramática da vida que deveria permanecer como chave de leitura para a avaliação de todas as lutas.

\section{A PANDEMIA E A NECROPOLÍTICA}

Por que o incômodo com a "metáfora da guerra"? Ele não seria proveniente de ingênuo pacifismo? Afinal, a guerra é coextensiva à história humana. Em meio à imensa destruição de vidas e bens culturais, Freud (1915/1969) já alertava:

Já dissemos a nós mesmos, sem dúvida, que as guerras jamais podem cessar enquanto as naçôes viverem sob condições tão amplamente diferentes, enquanto o valor da vida individual for tão diversamente apreciado entre elas, e enquanto as animosidades que as dividem representarem forças motrizes tão poderosas na mente (p. 312). 
O homo politicus, bem sabia Freud, também era o homo violens. "Por que não aceitar a guerra simplesmente como um fato biológico dentre tantos outros?", indagava Freud (1932-1933) em sua correspondência a Einstein:

Por que o senhor, eu e tantas outras pessoas nos revoltamos tão violentamente contra a guerra? Por que não a aceitamos como mais uma das muitas calamidades da vida? Afinal, parece ser coisa muito natural, parece ter uma base biológica e ser dificilmente evitável na prática. Não há motivo para se surpreender com o fato de eu levantar essa questão. Para o propósito de uma investigação como esta, poder-se-ia, talvez, permitir-se usar uma máscara de suposto alheamento. A resposta à minha pergunta será a de que reagimos à guerra dessa maneira, porque toda pessoa tem o direito à sua própria vida, porque a guerra póe um término a vidas plenas de esperanças, porque conduz os homens individualmente a situaçôes humilhantes, porque os compele, contra a sua vontade, a matar outros homens e porque destrói objetos materiais preciosos, produzidos pelo trabalho da humanidade (p. 206, grifos nossos).

Porque, apesar da frequência da guerra, não podemos banalizar a violência e não podemos fazê-lo justamente porque nos constituímos como homo politicus, isto é, vocacionados pelo próprio exercício da razão e da linguagem ao desenvolvimento da sociabilidade e da consciência moral.

Freud escreveu em 1915, no contexto da guerra travada entre as grandes potências europeias, e respondeu à carta de Einstein em 1932, quando o fantasma de uma nova guerra já rondava novamente a Europa e era preciso mobilizar esforços para evitá-la. No entanto, apesar de inúmeras guerras locais, há 75 anos não mais ocorreu uma guerra de grandes proporções envolvendo potências mundiais ou de grande porte, e o Brasil sempre esteve à margem desses grandes embates bélicos. No entanto a violência em nosso país, sendo intensa e interna, endêmica e estrutural, não é menos terrível.

A metáfora da guerra contra a pandemia, ao convocar à mobilização unitária da sociedade contra um "inimigo" externo, bem pode mascarar tal desigualdade histórica, divisão interna violenta e implacável. A pandemia, em princípio, atinge a todos, mas não é democrática. Evidencia o que já há entre nós: moradias pequenas, improvisadas e amontoadas, ausência de condições sanitárias mínimas, trabalho instável, sem garantias e baixa remuneração, ausência de infraestrutura sanitária, pobreza simbólica, enfim, exclusão das condições imprescindíveis para viver com dignidade e obter o reconhecimento social. Assim, apesar de a ordem jurídica repousar na proclamação formal dos direitos humanos, sua efetivação é estruturalmente barrada. Desse modo, ainda que a reiteração da proclamação dos direitos possa ter valor argumentativo na discussão ética e política, o constante desencontro entre o real e o ideal produzem o descrédito crônico em grande parte da sociedade e o discurso cínico das elites e políticos profissionais. Palavras como justiça, liberdade, igualdade, dignidade e todo o vocabulário associado aos 
direitos humanos podem ser utilizadas a bel-prazer, porque tacitamente se sabe que, além da retórica, de nada valem.

As cenas dantescas da pandemia: hospitais superlotados, falta de atendimento minimamente adequado, carência de tudo, de máscaras a médicos, valas comuns, aglomerações de pessoas em busca de um auxílio mínimo, cenas de desespero, tudo o que ocorre na rotina comum da miséria, mas que agora se intensifica e emerge na mídia como imagem de uma ameaça global, evidenciam o lado mortífero de nossa sociedade. Mas se a culpa de tudo for atribuída ao vírus, inimigo invisível, onipresente e altamente destrutivo, então a guerra justa contra ele oculta a necropolítica há tanto tempo ou, talvez, desde sempre, em curso em nosso país.

O termo "necropolítica" foi apresentado no ensaio do historiador e filósofo camaronês Achille Mbembe, ao empreender a releitura do conceito foucaultiano de "biopoder", mostrando que atualmente o poder não visa mais a enquadrar os corpos nos sistemas disciplinares e controlar a vida das populaçôes, mas, antes, identifica a soberania política como "poder da morte" ou como a decisão acerca de "quem pode viver e quem pode morrer" (Mbembe, 2016, p. 123). Mbembe retoma a ideia desenvolvida por Agamben, de uma figura do direito romano arcaico, a de homo sacer, definido como figura segundo a qual "a vida humana é incluída no ordenamento unicamente sob a forma de sua exclusão (ou seja, de sua absoluta matabilidade)" (Agamben, 2007, p. 16). O filósofo italiano mostra, então, a analogia estrutural entre a sacratio, a condição própria aos homines sacri, e a exceção soberana como "dois limites extremos do ordenamento [. . .] duas figuras simétricas [. . .] correlatas" ao definir como soberana: "[. . .] a esfera na qual se pode matar sem cometer um homicídio e sem celebrar um sacrifício, e sacra, isto é, matável e insacrificável, é a vida que foi capturada nesta esfera" (Agamben, 2007, pp. 91-92).

A vida matável é aquela despida de toda qualificação política, designada por Agamben, retomando uma expressão de Walter Benjamin, como "vida nua" (bloß Leben). A nudez reduz o sujeito de direito a indivíduo puro e simples que, excluído do sistema social e simbólico, pode ser morto ou eliminado como um elemento do cálculo político, anônimo e indiscernível e carente de todos os atributos que definem a pessoa humana. E quem são os homines sacri de nossa contemporaneidade ocidental e globalizada? Eles são todos aqueles engolidos pelo mecanismo mortífero da necropolítica atual. Como mostra Mbembe (2014), se na época moderna (s. XV-XIX), sob a dominação do tráfico atlântico de escravos "homens e mulheres originários da África foram transformados em homens-objecto, homens-mercadoria e homens-moeda" (p. 12), na última fase do sistema-mundo (s. XXI), "da globalização dos mercados, da privatização do 
mundo sob a égide do neoliberalismo e da crescente complexificação da economia financeira, do complexo militar pós-imperial e das tecnologias eletrônicas e digitais" (p. 13), ocorre o "devir-negro do mundo" (p. 18).

Como entender a expressão de Mbembe? Em primeiro lugar, a escravização torna-se planetária, englobando todos aqueles que não têm "competência" para se integrar na lógica neoliberal, segundo a qual, atualmente,

Já não há trabalhadores propriamente ditos. Só existem nômades do trabalho. Se ontem, o drama do sujeito era ser explorado pelo capital, a tragédia da multidão, hoje é já não poder ser explorada de modo nenhum, é ser relegada a uma "humanidade supérflua", entregue ao abandono, sem qualquer utilidade para o funcionamento do capital (Mbembe, 2014, p. 14).

A figura do escravo como a de "homens-objeto" se generaliza, como se vê no processo de favelização dos grandes centros urbanos. Mas, em segundo lugar, e não menos importante, é que não mais se pode identificar um responsável por essa situação de abandono, de superfluidade, de nudez e matabilidade, porque o mundo que se torna negro também deixa de ser mundo, para se transformar em coisa, mercadoria, funcionalidade e troca generalizada. Se não há mais mundo entendido como uma comunidade capaz de partilhar uma visão compreensiva da realidade, então os "homens-objeto" tornam-se, conforme a expressão de Heidegger (2011), "carentes de mundo" (weltlos) (pp. 205-208), são lançados à sua própria sorte, como uma pedra, uma coisa qualquer (Drawin, \& Moreira, 2014, p. 19). Quem é responsável? Ninguém. As coisas são assim, e cabe a cada um se adaptar ao curso das coisas. Que cada um arque com ou seu fracasso ou se modifique para tornar-se um vencedor. Numa entrevista ao Sunday Times, em 7 de maio de 1988, Margaret Thatcher resumiu a nova racionalidade de modo exemplar: "Economics are the method. The object is to change the soul" (A economia é o método. O objetivo é mudar a alma) (Thatcher apud Dardot, \& Laval, 2016, p. 331).

A desigualdade, a exclusão, a pobreza, a precariedade, enfim, a violência e a morte são fenômenos naturais pelos quais não há responsáveis ou culpados. Se agora, com a pandemia, a injustiça do mundo se evidencia e surge em imagens chocantes na consciência cotidiana, então a causa natural pode ser identificada: o vírus. Contra ele é que se deve declarar guerra, como se antes da pandemia tudo estivesse andando regularmente e as desordens, pois certamente as há, como a criminalidade, podem ser catalogadas como processos patológicos, doenças a serem combatidas visando à restauração da paz e da ordem sociais. 
No momento dramático da pandemia, a convocação de todos para a guerra, a convocação solidária contra o inimigo comum, embora justificável como medida de emergência e apelo necessário para o isolamento social, também pode servir como anverso da necropolítica, a morte visível produzida pelo vírus revestindo a morte invisível dos excluídos e descartáveis, dos "matáveis" de sempre.

No tempo da pós-pandemia, nada indica o nascimento de um mundo mais solidário e mais justo. Com os países mais ricos e poderosos do mundo sendo engolfados por profunda e duradoura crise econômica, a ilusão da prosperidade tende a desvanecer e, em seu lugar, pode se instalar a revolta e a frustração ou, quem sabe, a apatia, o cansaço e a desmotivação. A fábula do enriquecimento automático, alcançável para os competentes, desde que as coisas sigam seu curso, talvez se torne mais frágil a exigir um novo emprego da metáfora da guerra. $\mathrm{O}$ vírus, inimigo da vida de hoje, pode vir a se tornar o aliado da política da morte de amanhã.

\section{CONSIDERAÇÕES FINAIS}

As metáforas não são expedientes artificiais, porque seu uso traduz a força viva da língua, porque esta não se reduz às descrições empíricas ou aos objetivos pragmáticos, mas reenviam os significados mais comuns e corriqueiros a outros universos de sentido. No entanto, elas também podem se tornar banais e cristalizadas, esvaziadas de riqueza semântica e isso ocorre com a repetição excessiva. Mas há outro risco a considerar: quando o deslocamento metafórico, em vez de enriquecer e potencializar a realidade que se quer mostrar, acaba por encobrir e dissimular a própria realidade na qual estaria originariamente enraizada.

Nos tempos dramáticos em que vivemos (a requererem de nós virtudes há muito esquecidas, como a solidariedade, a humildade e a paciência, entre tantas outras), é bastante compreensível o uso retórico da metáfora da guerra no enfrentamento da terrível pandemia de covid-19 e no necessário apelo à mobilização social a favor do isolamento social. Nessas reflexões, nada obsta a tal uso a buscar a força afetiva requerida pela aprendizagem social. Aí nada haveria a censurar. Bem ao contrário, quisemos ressaltar apenas como a luta pela vida pode nos comover de modo meramente episódico e superficial.

A primeira parte do texto trouxe, em brevíssimas pinceladas, alguns elementos da abordagem midiática da pandemia. Na segunda parte, relembramos como os direitos humanos nascem da firme oposição e rejeição da guerra e, finalmente, procuramos assinalar como há guerra na aparente ausência de guerra, recorrendo 
ao conceito de necropolítica, de modo a assinalar a violência subjacente à suposta paz da ordem social. 


\section{REFERÊNCIAS}

Agamben, G. (2004). Estado de exceção. I. D. Poleti (Trad.). São Paulo: Boitempo.

Agamben, G. (2007). Homo sacer: o poder soberano e a vida nua. (Vol. 1). H. Burigo (Trad.). Belo Horizonte: Editora UFMG.

Clausewitz, C. (2010). Da guerra. (3a ed.). São Paulo: WMF Martins Fontes.

Dardot, P., \& Laval, C. (2016). A nova razão do mundo: ensaio sobre a sociedade neoliberal. M. Echalar (Trad.). São Paulo: Boitempo.

Drawin, C. R., \& Moreira, J. O. (2014). Reflexôes sobre a lógica social da violência. In M. Souza, F. Martins, \& J. N. G. Araújo (Orgs.), Violências e figuras subjetivas: investigaçôes acerca do mal incontrolável. (pp. 15-35). Florianópolis: Editora da UFSC.

Etienne, C. F. (2020, 31 março). Tempo para desacelerar propagação da COVID-19 está diminuindo nas Américas; países devem agir agora. Organização Pan-Americana de Saúde, Brasília. Recuperado a partir de https:// www.paho.org/pt/news/31-3-2020-time-essence-countries-americas-mustact-now-slow-spread-covid-19

Fernandes, R. C. (2020, 29 abril). Covid-19: presidente de El Salvador usa pandemia para fazer guerra aos gangs. Público. Recuperado a partir de https:// www.publico.pt/2020/04/29/mundo/noticia/covid19-presidente-el-salvadorusa-pandemia-guerra-gangues-1914237

Freud, S. (1915/1969). Reflexões para os tempos de guerra e morte. In J. Salomão (Trad.), J. Strachey (Ed.), Edição standard brasileira das obras psicológicas completas de Sigmund Freud. (Vol. 14). Rio de Janeiro: Imago, 1969. (Publicado originalmente em 1915).

Freud, S. (1932-1933/1969). Por que a guerra? (Einstein e Freud). In J. Salomão (Trad.), J. Strachey (Ed.) Edição standard brasileira das obras psicológicas completas de Sigmund Freud. (Vol. 22). Rio de Janeiro: Imago. (Publicado originalmente em 1932-1933).

Foucault, M. (2005). Em defesa da sociedade: curso no Collège de France (19751976). M. E. Galvão (Trad.). São Paulo: Martins Fontes. 
Geertz, C. (1978). A interpretação das culturas. Rio de Janeiro: Zahar.

Heidegger, M. (2011). Os conceitos fundamentais da metafisica: mundo, finitude, solidão. M. A. Casanova (Trad.). (2a ed.). Rio de Janeiro: Forense Universitária.

Jonas, H. (2006). O princípio responsabilidade: ensaio de uma ética para uma civilização tecnológica. Rio de Janeiro: Editora PUC Rio.

Kant, I. (2009). Fundamentação da metafísica dos costumes. I. A. Lohbauer (Trad.). São Paulo: Martin Claret, 2009.

Mbembe, A. (2014). Crítica da razão negra. M. Lança (Trad.). Lisboa: Antígona.

Mbembe, A. (2016, dezembro). Necropolítica. Arte \& Ensaios, 32, 123151. Recuperado a partir de https://revistas.ufrj.br/index.php/ae/article/ view/8993/7169

Motlagh, J. (2019, 3 maio). A guerra de gangues e a pobreza dizimam El Salvador. National Geographic. Recuperado a partir de https://nationalgeographic.sapo. pt/historia/grandes-reportagens/2089-a-guerra-de-gangues-e-a-pobrezadizimam-el-salvador

Nascimento, E. (2020, 19 abril). Com quase 90\% de leitos para Covid-19 ocupados, AM vive corrida para evitar colapso; 'disponibilidade já era insuficiente', diz secretária. G1, Amazonas. Recuperado a partir de https:// g1.globo.com/am/amazonas/noticia/2020/04/19/com-quase-90percentde-leitos-para-covid-19-ocupados-am-vive-corrida-para-evitar-colapsodisponibilidade-ja-era-insuficiente-diz-secretaria.ghtml

OMS declara coronavírus emergência de saúde pública internacional. (2020, 30 abril). Naçôes Unidas Brasil. Recuperado a partir de https://nacoesunidas.org/ oms-declara-coronavirus-emergencia-de-saude-publica-internacional/

Rodríguez, A. (2020, 23 abril). Covid-19 y la metáfora de la guerra. In M. Moya, G. B. Willis, D. Paez, J. A. Pérez, Á. Gómez, J. M. Sabucedo, . . . M. Salanova,(Orgs.), La Psicología social ante el COVID-19: monográfico del International Journal of Social Psychology (Revista de Psicología Social). (pp. 3037). Cartuja: Universidad de Granada. Recuperado a partir de https://psyarxiv. $\mathrm{com} / \mathrm{fdn} 32 /$

Sanches, M. (2020, 29 março). Brasil deveria fazer 'esforço de guerra' para manter as pessoas em casa, diz economista da Universidade de Chicago. 
BBC News Brasil. Recuperado a partir de https://www.bbc.com/portuguese/ brasil-52079780

Senra, R. (2020, 16 abril). 'É como ir para a guerra sem nenhuma arma': médicos e MP relatam caos no Amazonas com a pandemia. BBC News Brasil. Recuperado a partir de https://www.bbc.com/portuguese/brasil-52317263

World Health Organization. (2020, March, 26 ${ }^{\text {th }}$ ). Director-General calls on G20 to Fight, Unite, and Ignite against COVID-19. Geneve: WHO. Recuperado a partir de https://www.who.int/news-room/detail/26-03-2020-who-s-directorgeneral-calls-on-g20-to-fight-unite-and-ignite-against-covid-19 